\title{
Failing Fontan assist: From tissue to turbine
}

\author{
From the Department of Cardiovascular Surgery, Children's National Heart Institute, The George Washington \\ University School of Medicine and Health Sciences, Washington, DC. \\ Disclosures: Authors have nothing to disclose with regard to commercial support. \\ Received for publication Aug 26, 2018; accepted for publication Aug 27, 2018. \\ Address for reprints: Can Yerebakan, MD, Cardiovascular Surgery, Children's National Heart Institute, The \\ George Washington University School of Medicine and Health Sciences, 111 Michigan Ave NW, Washington, \\ DC, 20010 (E-mail: cyerebakan@childrensnational.org). \\ J Thorac Cardiovasc Surg 2018;156:1947-8 \\ $0022-5223 / \$ 36.00$ \\ Copyright (C) 2018 Published by Elsevier Inc. on behalf of The American Association for Thoracic Surgery \\ https://doi.org/10.1016/j.jtcvs.2018.08.060
}

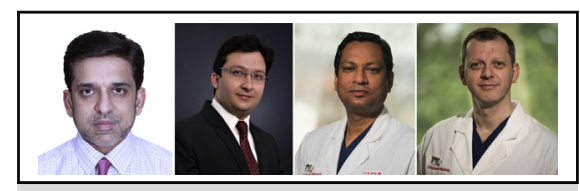

Left to right: Syed Bukhari, MD, Manan Desai, MD Lok Sinha, MD, and Can Yerebakan, MD

Central Message

The search for an effective treatment for a failing Fontan circulation is in persistent evolution.

See Article page 1949.
There have been significant advances in the performance of Fontan completion after its first description by Fontan. ${ }^{1,2}$ Contemporary changes have failed to fix the ultimate failing Fontan physiology with its various reasons, however, rendering a significant patient population into a state of debilitated illness that places a major burden to families and economy. ${ }^{3-5}$ Despite the significant challenges and constant effort, the search for ideal fourthstage management of single-ventricle palliation continues. ${ }^{6}$

In this issue of the Journal, the excellent report by Broda and collagues ${ }^{7}$ offers an overview of potential treatment options to support a failing Fontan circulation, extending from tissue-engineered products to turbine devices, some of which have already been used in the clinical setting. Broda and collagues ${ }^{7}$ are to be congratulated on their clear and comprehensive description of support options in patients with a failing Fontan circulation. Several novel ideas in search of an ideal support in a failing Fontan physiology give a glimpse of hope on the horizon.

Among different causes of Fontan failure, the missing subpulmonary ventricle is the subject of ongoing efforts to find a reliable substitute for long-term effective and simple assistance in cases of a preserved cardiac function. The use of available mechanical ventricular assist devices in patients with a failing Fontan circulation in the low-pressure passive venous circulation is suboptimal. Despite the challenges with each of these models mentioned by Broda and colleagues, $^{7}$ moving forward with philosophical skepticism, these novel approaches may offer a way to improve the outcome for patients with Fontan failure physiology in the future. A prime example of an in vitro model of turbine pump is the feasibility study of an integrated aortic turbine venous-assist system in a mock Fontan circuit presented recently in the Journal by Pekkan and colleagues. ${ }^{8}$ In this ingenious model, the aortic bloodstream is used as a source of kinetic energy to reduce the venous pressure and augment the flow in a Fontan circulation, similar to a turbine used in hydropower to generate electricity. Even with the device in its early developmental phase, the approach whispers the key elements of how an ideal support device should look in the future. One of the most promising devices as of today is Rodefeld's von Karman pump. ${ }^{9}$ The challenge with this pump is to convert it into an actual implantable device and to test it biologically with a reliable long-term animal model of Fontan circulation.

Being optimistic about the future perspectives that are offered by ongoing research efforts today's reality will keep us in continuous skepticism. Thrombogenicity will remain a major concern, weighed against the risk of bleeding, because the right-sided low-pressure system will require higher therapeutic levels of anticoagulation with the use of mechanical support devices that are exposed to blood. Alternatively, external counterpulsation devices and tissue engineering remain significant alternatives. ${ }^{7,10}$ Recent advances in technology with wireless and transcutaneous charging feasibility, however, provide hope that the ideal miniature and less thrombogenic assist devices without a driveline will also be in the pipeline as primary competitors of tissue-engineered support alternatives. $^{11}$

Although the progress in last 2 decades has been in the direction of continuous improvement, regardless of the diversity of ideas and challenges, the search for ideal support system for a failing Fontan circulation should be encouraged to achieve the ultimate beyond the known. The ultimate therapy for a failing Fontan may just be its prevention by novel surgical and medical means in the future. We congratulate Broda and collagues ${ }^{7}$ on their comprehensive summary of today and anticipated future of failing Fontan treatment.

\section{References}

1. Fontan F, Baudet E. Surgical repair of tricuspid atresia. Thorax. 1971;26:240-8.

2. Jonas RA. The intra/extracardiac conduit fenestrated Fontan. Semin Thorac Cardiovasc Surg Pediatr Card Surg Annu. 2011;14:11-8. 
3. Schilling C, Dalziel K, Nunn R, Du Plessis K, Shi WY, Celermajer D, et al. The Fontan epidemic: population projections from the Australia and New Zealand Fontan registry. Int J Cardiol. 2016;219:14-9.

4. Pundi KN, Johnson JN, Dearani JA, Pundi KN, Li Z, Hinck CA, et al. 40-year follow-up after the Fontan operation: long-term outcomes of 1,052 patients. $J$ Am Coll Cardiol. 2015;66:1700-10.

5. Collins RT II, Fram RY, Tang X, Robbins JM, Sutton MS. Impact of anatomical subtype and medical comorbidities on hospitalizations in adults with single ventricle congenital heart disease. Int J Cardiol. 2013;168:4596-601.

6. Jaquiss RD, Aziz H. Is four stage management the future of univentricular hearts? Destination therapy in the young. Semin Thorac Cardiovasc Surg Pediatr Card Surg Annu. 2016;19:50-4.

7. Broda CR, Taylor DA, Adachi I. Progress in experimental and clinical subpulmonary assistance for Fontan circulation. J Thorac Cardiovasc Surg. 2018;156:1949-56.
8. Pekkan K, Aka I, Tutsak E, Emek E, Balim H, Lazoglu I, et al. In vitro validation of a self-driving aortic-turbine venous-assist device for Fontan patients. J Thorac Cardiovasc Surg. 2018;156:292-301.e7.

9. Rodefeld MD, Coats B, Fisher T, Giridharan GA, Chen J, Brown JW, et al. Cavopulmonary assist for the univentricular Fontan circulation: Von Karman viscous impeller pump. J Thorac Cardiovasc Surg. 2010; 140:529-36.

10. Biermann D, Eder A, Arndt F, Seoudy H, Reichenspurner H, Mir T, et al. Towards a tissue-engineered contractile Fontan-conduit: the fate of cardiac myocytes in the subpulmonary circulation. PLoS One. 2016;11: e0166963.

11. Waters BH, Sample AP, Bonde P, Smith JR. Powering a ventricular assist device (VAD) with the free-range resonant electrical energy delivery (FREE-D) system. Proc IEEE. 2012;100:138-49. 